\title{
Liquidation Values and Debt Capacity: A Market Equilibrium Approach
}

\section{Citation}

Shleifer, Andrei, and Robert W. Vishny. 1992. "Liquidation Values and Debt Capacity: A Market Equilibrium Approach." The Journal of Finance 47 (4) (September): 1343-1366. Portico. doi:10.1111/j.1540-6261.1992.tb04661.x.

\section{Published Version}

doi:10.1111/j.1540-6261.1992.tb04661.x

\section{Permanent link}

http://nrs.harvard.edu/urn-3:HUL.InstRepos:27692663

\section{Terms of Use}

This article was downloaded from Harvard University's DASH repository, and is made available under the terms and conditions applicable to Other Posted Material, as set forth at http:// nrs.harvard.edu/urn-3:HUL.InstRepos:dash.current.terms-of-use\#LAA

\section{Share Your Story}

The Harvard community has made this article openly available.

Please share how this access benefits you. Submit a story.

Accessibility 
NBER WORKING PAPERS SERIES

ASSET SALES AND DEBT CAPACITY

Andrei Shleifer

Robert W. Vishny

Working Paper No. 3618

\author{
NATIONAL BUREAU OE ECONOMIC RESEARCH \\ 1050 Massachusetts Avenue \\ Cambridge, MA 02138 \\ February 1991
}

We are grateful to Eugene Fama, Robert Gertner, Milton Harris, Glenn Hubbard, Steven Kaplan, Robert McDonald, Merton Miller and Artur Raviv for helpful comments. We are also grateful to the NSF, Bradley and Sloan Foundations, and Dimensional Fund Advisors for financial support. First draft, August 1990. this draft, January 1991. This paper is part of NBER's research program in Financial Markets and Monetary Economics. Any opinions expressed are those of the authors and not those of the National Bureau of Economic Research. 


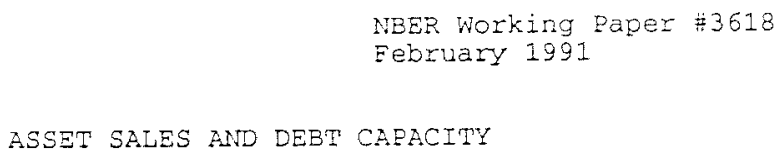

\section{ABSTRACT}

In this paper, we explore the link between asset sales and debt capacity. Asset sales are a common way for firms to raise cash, and so present an alternative to security issues for firms near Einancial distress. We argue that liquid assets -- those that can be resold at attractive terns - are good candidates for debt finance because financial distress for firms with such assets is relatively inexpensive. We apply this logic to explain variation in debt capacity across industries and over the business cycle, as well as to the rise in U.S. corporate leverage in the $1980 \mathrm{~s}$.

Andret Shleifer

Harvard University

Cambridge, MA 02138
Robert W. Vishny

University of Chicago

Chicago, IL 60637 
1. Introduction.

How do firms choose debt levels, and why do firms or even. whole industries sometimes change how much debt they have? Why, for example, have American firms increased their leverage tremendously in the 1980 s (Bernanke and Campbell 1988, Warshawsky 1990), and why has this debt increase been the greatest in some industries, such as food and timber? Despite substantial progress in research on leverage, these questions remain largely open. In this paper, we explore an approach to debt capacity based on the cost of asset sales. We atgue that this approach helps understand the crosssectional determinants of leverage, and also sheds light on the debtincreases of the 1980 s. Asset sales are an effective way in which firms can generate cash fast, pay off some debt and reduce leverage: A lot of assets are sold by perfectly healthy firms, which might need cash to acquire other assets or to invest internally. In the 1980s, many companies in very good shape sold divisions. But asset sales are also used by firms in Einancial trouble to raise cash and avoid default on their debt. As the examples of Texaco, Pan Am and many LBOs illustrate, for highly leveraged firms asset sales are common both in and out of bankruptcy.

For roubled firms selling assets is an alternative to conventional financial restructuring, such as debt rescheduling, issuing equity to the public or obtaining fresh loans. Much research has shown that these means of restructuring can be very costly to the firm. 
Rescheduling debt creates free rider problems, whereby bondholders hold out for a better deal when they think other bondholders are agreeing to a rescheduling. Gertner and Scharfstein (1990) show that these probiems can be severe. Issuing equity has the well known problem of buyer concern that only overvalued firms issue equity. As Myers (1984) shows, this asymmetric information problem substantially raises the costs of equity issue. In addition, a public equity issue preserves the control of possibly incompetent incumbents, which keeps down the prices investors are willing to pay. Issuing new debt is often no easier than issuing equity, because buyers of new debt are the last in line in claiming the firm's cash flow. The costs of raising new money to pay interest and fund necessary capital expenditures are thus often prohibitive. These costs of financial-restructuring are well understood in the literature.

Asset sales are a form of financial restructuring that is often more attractive than the approaches mentioned above. Such a sale can have two advantages over a public equity issue. First, the buyer of this equity claim can be better informed about its true value than a diffuse set of outside shareholders who buy the public equity issue. This would be particularly important if the buyer is already in the same industry as the assets being sold. Second, unlike in a public equity sale the buyer gains effective control of the assets, and so can reduce agency costs by for example replacing the manager. These factors suggest that asset sales might be an attractive alternative to the conventional financial restructuring. 
In fact, some legal scholars have advocated automatic liquidation of firms in financial distress, on the theory that such liquidation allocates assets to the highest value users and so is cheap and efficient. Financial economists, in contrast, have typically assumed that liquidation is costly, and focused on traditional financial restructuring without spelling out why selling assets is more costly. This paper focuses on the cost of asset sales to gain greater insight into this alternative to conventional financial restructuring. By doing so, we describe this other aspect of the costs of financial distress. Since troubled firms presumably choose the cheapest way of dealing with distress, we hope that this study will provide further insight into corporate debt capacity.

The cost of asset sales that we focus on is the liquidity cost, detined as the difference between the net present value of an asset's cash hows in best use and the price it fetches in a quick sale. Some assets, like commodities, are extremely liquid and can be easily sold fast at a price close to value in best use. Other assets, such as tankers or oil rigs might fetch very low prices relative to value in best use when sold rapidly. Part of the problem may be the scarcity of buyers who can use the asset; the asset may be non-fungible and some buyers may be precluded from bidding by regulation such as antitrust. Perhaps as important is the problem of costly credit to the buyers. At the time an asset is sold buyers from the same industry are often themselves in financial trouble and so can pay only a fraction of the full value of the asset in their use. To gauge the cost of asset sales, we focus on the potential buyers: their participation and ability to pay. 
Limited asset liquidity implies that asset sales, like equity issues, can be very costly to the Erm. The costs of financial distress are then high regardless of how the firm deals with it. This in tum implies that corporate debt capacity is limited, and more so for firms with illiquid assets. This result allows us to reinterpret some of the available evidence on cross-sectional financing patterns and to generate some new predictions.

Moreover, asset liquidity changes over time, as buyer participation and ability to pay changes. As a consequence, debt capacity changes over time, and in particular becomes very high when assets are very liquid. We rely on changes in asset liquidity over time to explain why high markets tend to be liquid markets, why takeover waves are procyclical, and why increases in leverage in the 1980s have occured in some but not all industries.

The next section sets out the "buyer" approach to the liquidity of assets. Sections 3 through 5 deal with the various types of potential buyers, and what limits the prices they pay for assets. Section 6 spells out the relationship between asset liquidity and debt capacity. Section 7 presents the implications of changes of liquidity over time, and section 8 applies the analysis to takeovers and leverage increases in the 1980s. Section 9 conciudes.

2. Determinants of asset liquidity: an overview.

To fix ideas, consider a heavily indebted farmer whose farm is not currently generating a sufficient cash flow to cover both his interest payments and necessary capital 
expenditures. Assume, as we do throughout this paper, that it is costly to this farmer to borrow more or to issue equity in his farm. The lenders are unsure about the quality of the farmer and his land, and suspect that he is selling overvalued securities. In addition, the farmer cannot get a new mortgage because it would be junior to his current one. In this case, the farmer must sell all or a part of his farm to avoid tuming it over to the bank.

There are three distinct types of potential buyers of the land. It can be sold to an outsider who would convert it to a baseball field or some other use. It could be sold to a neighbor who would farm it himself. Finally, it could be sold to a New York deep pocket investor who would hire the current or some other farmer to farm the land, at least until he could find a higher value buyer. This list of alternative buyers pretty much exhausts the relevant set for most assets. We argue below that each of these buyers may be unwilling to pay the price equal to value in best use.

Suppose that the asset, namely land, is converted to another use, such as the baseball field. If the land is as valuable as a baseball field as it is as a farm, this solution is very attractive in that the farmer gets a price close to the value in best use. He would do especially well if several people want to build a baseball field on his farm, and if they have access to credit. Fungible assets, such as a farm that can be made into a popular baseball field, tend to be liquid. But of course fams and other assets only rarely have alternative uses as good as the current use. In this case, baseball promoters will not be the buyers. 
When the land is not fungible, the more likely high valuation buyer is one of the neighboring famers. These buyers have the enormous advantage of knowing the quality of the land and perhaps even the quality of the current farmer. The adverse selection problems that might plague outsiders interested in the farm are much less important for the neighbors. Moreover, the neighbors can work the land themselves, thereby avoiding the agency problems resulting from hiring employees. In fact, if the neighbors are actually allowed to bid for the farm and if they have access to credit at attractive terms, they are likely to buy the farm. The competition between neighbors ensures a price close to value in best use, making the land very liquid.

The caveats of participation and credit are very important, however. First, neighbors might not be allowed to bid because of government limits on farm size (this is obviously more relevant for companies). In addition, unless the farmer got in trouble for some idiosyncratic reason such as mismanagement, the neighbors are likely to have cash flow problems of their own at the time the farmer is distressed. Because the neighbors' net worth is low as well, their cost of capital is high, and so they can bid much less for the farm than its fundamental value in their use. The credit constraint problems of the buyers are the result of concern of the buyers' lenders that he is undertaking a bad project or has the wrong incentives. This problem is particularly severe when the buyer's net worth, which determines the value of his collateral, is low. When buyers cannot participate, or when they face credit constraints, the price realized from the sale of the land is below value in best 
use, making this land illiquid.

In this case, the land would probably be sold to a deep pocket New York investor who does not face as severe credit constraints as the farmer's neighbors. Sale to such an investor has some of the same problems as simply swapping equity for some of the existing debt. The New York investor must worry about the quality of the farm, which he knows little about and so is afraid to overpay. In addition, the New York investor must hire either the current farmer or someone else to run the farm. The agency cost is a further burden on his purchase. Because of these adverse selection and moral hazard problems, the price that a deep pocket outsider will pay for the farm will again fall below value in best use. In this sale as well, the farm is illiquid.

The moral of the story is that regardless of whom the farm is sold to, it is likely to bring a price below value in best use. When the farmer decided on how much debt to take on, he must have thought of these problems and restricted his borrowing.

Table 1 summarizes the taxonomy of buyers considered in this paper. The first type of buyer changes the use of the assets, the second and third do not. The second type is industry insiders, defined as those with information about the quality of the asset and with the ability to manage it. The third type of buyers is industry outsiders who nonetheless keep the asset in current use. Such buyers typically cannot easily evaluate the quality of an asset, and must hire a manager to run it. To understand liquidity of a given asset, we must understand how much a buyer of each of these types will pay relative to value in best 
Table 1

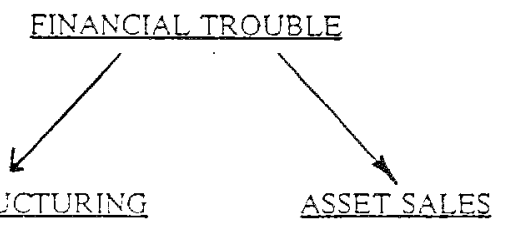

\section{ETNANCIAL RESTRUCTURING}

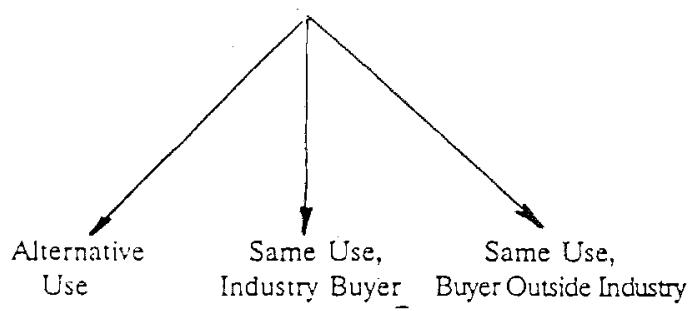


use. If any one of the three types of buyers can afford to pay close to value in best use, the asset is liquid. If none of the three types can, the asset is illiquid. The next three sections will focus on these three types of buyers.

3. Asser fungibility.

Sale of an asset brings a price close to value in best use when there are several participating buyers to whom the asset is worth nearly its value in best use. In some cases, the best use for an asset is different from the current use. For example, land can have many difterent things built on it; a building may be easily converted from one use to another, a car or truck can similarly be turned to another use; coal and oil can be used as an input by a variery of buyers. Assets which have several uses with comparably high valuations are called fungibie: Obviousiv, rost physical capital is fairly specialized and is not very tungible.

Fungible assets tend to be fairly liquid because they can be transferred to another use if buyers in this asset's current industry cannot pay prices close to value in best use ${ }^{2}$. This is particularly important when the whole industry in which the asset is currently used experiences an adverse shock, and so both the fundamental value and the liquidity of the asset is higher elsewhere. For example, many industrial buildings in downtown New York

${ }^{2}$ Even with fungible assets, there may be adverse selection problems resulting from buyer uncertainty about the quality of these assets. Such problems make the buyers more like deep pocket outsiders. Nonetheless, holding adverse selection problems constant, tungibility raises liquidity. 
were converted to residential use when manufacturers left the city. These buildings were liquid because they had an alternative use and so a seller did not need to dump them on industrial buyers who had low fundamental valuations and faced severe credit constraints. In contrast, non-fungible assets, such as oil tankers or machine tools, tend to be less liquid because they cannot be transferred to another industry when the industry they are employed in suffers an adverse shock.

Fungibility encompasses several characteristics of assets that other studies have described as conducive to debt finance. Titman and Wessels (1988) argue that asset uniqueness is bad and tangibility is good for debt finance. Their reason for focusing on uniqueness and tangibility is not liquidity, however. They argue that firms with unique assets are poor candidates for debt finance because customers cannot find substitutes for these firms' products, and so insist that such firms avoid debt finance and the resulting possibility of bankruptcy before they rely on their products. Titman and Wessels also argue that tangible assets are good candidates for debt finance because their value cannot easily be dissipated by management. The moral hazard problems with debt finance of these assets are less severe. For this reason, land is a good candidate for debt finance.

We would argue that non-unique and tangible assets are better candidates for debt finance primarily because they tend to be more liquid. Unique assets tend to be less liquid because by definition they have fewer potential uses and therefore fewer buyers. But even unique assets can be liquid, and therefore have debt capacity, when they are traded by deep 
pocket investors willing to pay prices close to values. For example, some fashion and food brand names, such as Gucci or Moet-Chandon, are very liquid because they have many interested buyers even though all these buyers put them to the same use. These assets are good collateral largely because they can be easily resold despite their unique use. Even if an asset is not very fungible, it can be liquid and have debt capacity when high valuation buyers participate and have money to bid.

Similarly, the essential aspect of tangibility of some assets such as general purpose buildings is that they have multiple uses and buyers, and so are fairly liquid. Some specialized rangible assets, such as oil rigs, wight not be very liquid at all even though they are quite durable and it is difficult for the user to substantially diminish their value. In contrast, some intangible assets, such as food brand names, have been extremely liquid in the 1980 s because of a large number of interested potentiul buyers. These assets' high debt capacity derives from their easy saleability their intangibility notwithstanding.

Williamson (1988) uses a concept of redeployability that is close to fungibility. He says that assets are good candidates for debt Finance if they can be used elsewhere. Debt is a hair-trigger mechanism which forces the redeployment of assets as soon as interest is not paid or some covenant is violated. Williamson stresses that non-unique and tangible assets might be good candidates for debt finance because they are easily redeployable.

Similarly, Harris and Raviv (1990) argue that debt levels will be set high enough to force managers to take value-enhancing liquidation decisions. When the value of assets in their 
current use falls below the value of the debt, a costly reevaluation is triggered. If the firm's assets are found to be more valuable in other use, the firm is liquidated. Ome implication of their theory is that leverage will be high where liquidation value is high.

These studies, like ours, show that assets with several alternative uses have a higher debt capacity. But fungibility is only one aspect of liquidity, and probably not the most important one. As we mentioned, most physical assets are not fungible, and so putting them to alternative use is impossible. Buyers of non-fungible assets must keep them in current use. In the next two sections, we examine the liquidity of such assets. In many cases, they have a high debt capacity as well.

4. Buyers in the same industry.

For most non-fungible and even fungible assets, the highest valuation buyers are those already using similar assets in the same way. In our earlier example, they are the next door farmers. These buyers have two critical advantages over all others. First, they can evaluate the assets most easily and so do rot worry as much as others about overpaying for low quality assets. Second, they know how to manage these assets and so the agency costs that they must incur are the lowest. For these reasons, buyers from the same incustry tend to value these assers the most. Moreover, when such buyers compete with each other, they will in many circumstances pay close to the value in best use for the assets.

Indeed, the vast majority of asset sales are to such buyers. Buildings are usually sold 
and bought by real estate developers, machine tools by manufactureres, and companies by other companies in their industry. As long as industry buyers are allowed to participate, and can afford to bid the value of assets under their management, assets tend to be liquid. The main reason for illiquidity of non-fungible assets is participation and credit restrictions on industry buyers.

\section{Participation restrictions.}

Several factors reduce participation of industry buyers and so create illiquidity. First, some markets are thin in that some buyers might not know about the asset being for sale, or might not show up. Athough an asset would be liquid if buyers are brought to bid, it is illiquid because some of them are not avalable. Such illiquidity is important in housing markets, where many potential buyers are not currently in the market, or in markets for smaller durable goods, where it is too costly to bring some of the buyers to the sale: Thinness is unlikely to be important in the market for companies, where the stakes are too large and the sale too widely publicized for important buyers not to show up.

In many cases, regulation is the reason that industry buyers do not participate, particularly in the sales of companies. For example, foreign buyers might be prevented from participating by protectionist laws. As the case of United Airlines illustrates, airlines as a whole and individual routes are cheaper because foreigners cannot bid for the United States airline assets. The same is true about assets of microchip manufacturers. 
Conversely, the United States takeover market has probably become much more liquid in the 1980 s as foreign buyers in most industries have been both actively interested and free to participate.

Antitrust has also been an important constraint on buyers, particularly before 1980 , since it eliminated comperitors from bidding. In the late 1960 s, for example, it was virtually impossible to sell assets to competitors because of aggressive antitrust enforcement. As a result, many conglomerates were formed. When competitors are highest valuation buyers, as they most commonly are even when they do not plan to raise prices, keeping them out dramatically reduces the liquidity of assets.

Finally, even when regulatory restrictions do not prevent an acquisition of assets by a firm in the same industry, there may be a problem of "compatibility" of buyers and sellers. Not every two firms in an industry are a good match: Even when one can manage the other's assets, there may be a probiem with control change because of different corporate cultures, difficulties of keeping key people, and problems of allocating control rights to managers and so on. Especially with intangible assets, where human capital is important, these participation restrictions further reduce asset liquidity.

\section{Credit Constrainis.}

The assumption that industry buyers can afford to pay the fundamental value of the asset under their ownership is often invalid because these buyers are constrained in the 
capital market. That is, it is costly for these buyers to raise external debt or equity capital for the exact same reason that such financing is costly for asset sellers. The cost of funds to these buyers exceeds the appropriate risk-adjusted discount rate for the asset, and so the asset is worth to them less than its fundamental value under their ownership.

Buyers of some assets, such as very large companies, are likely to always be credit constrained. No buyer can purchase GM or IBM with internal funds or even with a moderate amouni of borrowing. As a result, these assets are always illiquid. This reasoning suggests that smaller assets are more liquid than larger assets, and that assets that can be broken up, such as conglomerates, are more liquid than assets that cannot be, such as pure play firms of equal size.

Equally important, industry insiders are likely to be credit constrained precisely at the time when an asset used in this industry is put up for sale, since the whole industry is likely to be adversely affected at the same time. Precisely when the seller is credit constrained and needs to raise funds, potential buyers tend to be credit constrained themselves and therefore have lower reservation values. The reason for this, stressed by Greenwald et al (1984), Bernanke and Gertler (1989), Gertler and Hubbard (1988), Froot and Stein (1991) and others, is that when buyers net worth is low, lenders demand higher returns on the loans they make to control adverse selection and moral hazard problems. With industry or economy-wide shocks, sellers and buyers of assets are in a symmetric situation: they both have a low net worth and so both have a very high cost of external 
finance. This problem makes asset saies to industry buyers costly, just as it makes conventional financial restructuring costly.

Consider a hypothetical case of an airine (Eastern) that puts its gates, routes, and planes up for sale when it gets into trouble. One possibility is that the adverse shock Eastem has experienced is idiosyncratic; for example it has union problems. In this case, Eastern puts its assets up for sale when other airlines are doing well, and so are not credit constrained. These firms can then bid their true reservation vaiues for the assets of Eastern and as long as these assets are fungible enough, the auction will bring very attractive prices. In fact, if other airines can manage Eastern's assets better than Eastern, they will bid more for them then their value under Eastern's management, and the costs of financial distress will be negative. In this case, asset sales work very well from the viewpoint of Eastern's creditors since not only do these creditors avoid the problem of illiquidity but they aiso benefit from the reallocation of assets to higher valued use ${ }^{3}$.

If, in contrast, that Eastern puts its assets on the block at the time that the rest of the airline industry is in a downturn as well, perhaps as a result of an oil price shock, a recession or an overorcering of planes. In this case, at the time Eastern's assets are on the block, other airlines have a very high shadow price of funds, and so cannot afford to pay

${ }^{3}$ Negative costs of financial distress raise the obvious question of why the underperforming assets are not sold even without financial distress. Clearly, the firm's managers as opposed to its creditors and shareholders may be reluctant to give up personal control of key assets unless forced to. Nonetheless, managers acting in their own interest will be more inclined to take on debt if a reasonable number of asset sales can extricate them from a control battle with creditors. 
their perfect capital market reservation values. As the willingness to pay falls, the sale price also fails below the second highest valuation absent credit constraints. In this case, airline assets are iliquid.

The point this example illustrates is more general. A firm is likely to run into financial trouble when its cash flow is low. If the reason for low cash flow is an industrywide or an economy-wide shock, then the cash flows of other firms in the industry are also low and their cost of capital is high. Other firms in the industry do not then value the distressed Erm's assets as much as they would absent credit constraints. But these firms probably have the highest fundamental valuations of the distressed firm's assets, since they can manage them better than industry outsiders and they are not as worried about adverse selection. Asset sales then bring low prices relative to fundamentals since the potentially highest bidders have a high cost of funds.

Several factors determine the liquidity of assets when industry buyers are credit constrained. Most important, assets with cyclical cash flows, suct as oil tankers and steel mills, are likely to be less liquid in recessions than assets with non-cyclical cash flows. Cyclical assets are extremely illiquid during recessions, when the cost of capital of industry buyers is nigh but are liquid during booms when it is low.

Similarly, the more distant are the cash lows on an asset, the less liquid it is. When cash flows are discounted using interest rates refiecting credit constraints; the value of distant cash flows is reduced. Growth assets are then discounted the most relative to 
fundamentals, whereas assets with high current and relatively low future cash flows are discounted the least.

Fungibility of assets also raises liquidity when industry buyers face credit constraints beyond its contribution with unconstrained buyers. When its industry experiences an adverse shock, a fungible asset can be transferred to another industry. Without credit constraints, it would only be transferred if it can generate a higher fundamental value there. But with credit constraints, an asset can be sold to a firm in another industry because that industry is not hit by an adverse shock and so is not facing credit constraints. By increasing the number of unconstrained buyers, fungibility raises liquidity.

We conclude that the ability of industry buyers to pay the fundamental value of this industry's assets in best use cannot be taken for granted. Industry buyers are often kept from bidding by regulation. In other cases, industry buyers face severe credit constraints and so can only afford prices that reflect this high cost of capital. The resulting illiquidity is particularly severe in recessions, and for cyclical, growth and non-fungible assets. Selling such assets to industry insiders would bring prices much below values in best use.

\section{Deep pocket buyers.}

The third type of potential buyer for an asset is deep pocket investors. These investors by definition have access to fairly inexpensive capital because their other assets give them a high net worh that can be used as collateral. 
Purchases by deep pocket investors are in some ways similar to Enancial restructuring such as the issue of new equity. Like buyers of equity these investors are likely to be less capable of evaluating the quality of the asset than industry insiders. In addition, deep pocket investors typically need to hire a manager to manage the assets, which entails agency costs. Unlike equity buyers, however, deep pocket investors gain control of the assets from the current managers, and so can design control mechanisms to reduce these agency costs. In particular, they can fire the current manager. In this respect, purchases by deep pocket investors may be superior to equity issues. Even so, the prices that such investors pay for the assets reflect the adverse selection and moral hazard problems that they will face with these assets. In this case, assets sold to such investors fetch prices betow values in best use.

Access to cheaper capital gives deep pocket buyers an edge over industry insiders. On the other hand, their inferior knowledge and ability to manage assets puts them at a disadvantage relative to industry insiders. Presumably, they acquire the assets when these problems do not reduce valuation as much as the credit constraints of industry insiders do. This is the case when the deep pocket investors can learn to both evaluate and to manage the assets. Such deep pocket investors can be in related industries, so they can bring some of their knowledge to bear on the acquisition. In addition, deep pockets investors might be attracted to assets which are in relatively stable industries and so are relatively easy to manage. Chandler (1990) argues that such assets are particularly attractive for 
conglomerate acquirers, who can be thought of as deep pocket investors.

There are many examples of deep pocket investors who have to some extent overcome their informational and managerial handicaps. Cellular telephone properties are traded by phone companies, who are deep pccket investors who understand these assets. As a result, cellular telephone properties are extremely liquid ever though they are intangible growth assets. The reason is that they can always be sold to deep pocket telephone companies. Similarly, food brand names, which are not fungible, have recently become very liquid because they are traded by deep pocket tobacco companies that have tried to solve some of the agency and adverse selection problems that plague other deep pocket investors. Finally, in our airline examples, leasing companies represent such deep pocket investors who use detailed contracts designed to avoid the need to dump planes on the market when airlines' cash flow is low. When deep pocket investors manage to solve the information problems inherent in purchases of assets outside their industry, they become an effective substitute for industry buyers and so greatly enhance the liquidity of assets.

Such lucky outcomes are not pervasive, however. In many cases, deep pocket investors are the uninformed buyers who might have trouble valuing and managing the assets. In these cases, these buyers require deep discounts to buy the assets. In our example, when Eastern's assets are put up for sale, the high bidders might be deep pocket investors who have a lower fundamental valuation of assets as well as a greater fear of overpaying but also a lower shadow price of funds. In fact, successful buyers of the assets 
need not even be the better managers; just the ones with the deepest pockets. Eventually, as liquidity improves, these buyers probably sell assets for a higher price to industry insiders who can afford to bid their true valuations. These buyers are thus providing temporary liquidity in a highly illiquid market. As long as the market for airline assets is illiquid, sale prices are even lower than the already low fundamental valuations.

The oil shipping business provides a similar example. As cash flows from that business temporarily plummeted in the mid $1980 \mathrm{~s}$, and tankers sold for scrap value, astute investors outside the industry stepped in and bought tankers, mothballing them instead of selling them for scrap. Five years later, these investors have made a 700 percent return on investment. The oil shipping business is now less risky and has a higher debt capacity.

These examples illustrate that assets might be extremely illiquid even when some deep pocket investors are in the market. When assets are not-fungible, industry buyers are credit constrained, and ourside deep pocket investors are not informed, assets are extremely illiquid. They cannot be sold for anwwhere near their fundamental value in best use.

6. Asset liquidity and debt capacity.

Asset illiquidity becomes particularly important for sellers in or near financial distress, who face the choice between selling assets and going through a costly financial

${ }^{4}$ Grossman and Miller (1988) provide a theory of liquidiry in which liquidity suppliers temporarily hold the asset while higher valuation buyers are brought in to buy it. Their theory applies to financial instruments which are vastly more liquid than the physical assets that we are concerned about. 
restructuring. Our analysis suggests that asset sales are not a panacea for a firm in financial distress, unless these assets are extremely liquid. Most assets however are not liquid. A distressed firm must then choose between costly financial restructuring, with all the problems identified in the literature, and costly asset sales. Either way, distress is costly.

When financial distress is costly, firms will choose their capital struciure to reduce the expected value of these costs. Having more debt in the capital structure raises the likelihood of default, and hence the need to either restructure or to sell assets. Because their sale is costly, illiquid assets are poor candidates for debt finance, and vice versa for liquid assets. This logic suggests that asset liquidity creates debt capacity because liquid assets are in effect better collateral.

Asset illiquidity might help explain relatively low debt equity ratios in the United States. Debt is significantly tax favored relative to equity in the United States even after taking account of personal taxes. If firms can sell assets costlessly when they become distressed, the only reason for them to avoid nearly complete debt finance is the managerial preference for independence. If, however, firms have to sell illiquid assets when they are in financial difficulty, or choose to sell illiquid assets to avoid expensive claimholder conflicts, debt avoidance becomes in the interest of shareholders as well.

It is hard to know how big the illiquidity costs of distress are. Real estate appraisers typically assume that the rapid sale of real estate leads to price discounts of 15 to 25 percent relative to the orderly sale that might take several months. Kaplan (1989) cites 
Merrill Lynch estimates that the distressed sale of the Campeau retail empire would bring about 68 percent of what an orderly sale would bring. The New York Times reported that the rapid sale discount on the Trump Shuttle may be as much as 50 percent. Holland (1989) cites discounts of 50 to 70 percent off normal prices in a case study of liquidation of assets of a machine tool manufacturer. Discounts of such magnitudes can drastically reduce or even eliminate the tax advantage of debt. Asset illiquidity may be the reason that firms use much less debt than is optimal in standard models.

Athough we have taken the shareholders" perspective on optirial debt levels, corporate managers also have selfish reasons to avoid debt when the firm's assets are illiquid. A firm's manager is rypically interested in mantaining his control of the tirm. If a firm with liquid assets runs into cash tlow problems, its managers can sell off some of these assets, pay down debr, and retain control. If, on the other hand, the firm's assets are illiquid, a manager cannot attractively sell some of them to generate cash. If he does not sell the assets and tries a conventional restructuring, he might lose control. If he sells illiquid assets at too low a price and pays down debt, he only worsens his future interest coverage problem and is likely to lose control anyway. It is clear that a manager committed. to keeping control of the firm will take on more debt when the firm's assets are more liquid, just like a manager maximizing shareholder wealth.

In addition to suggesting that debt capacity is limited, our approach has a variety of implications for cross-sectional financing patterns. Liquid assets should be more extensively 
financed by debt. We have already mentioned that fungible assets are liquid, because they have many different buyers and because some of these buyers are likely to have relatively mild credit constraints. As a result, fungible assets are better candidates for debt finance than non-fungible assets.

In contrast, growth and cyclical assets are iliquid because industry buyers are likely to have a high cost of funds when these assets are distressed. These assets are poor candidates for debt finance, unless they are commonly traded by deep pocket investors. Growth and cyclical assets are usually considered to be poor candidates for debt finance because they have a high probability of a low cash flow and default on debt. But even an asset with a reasonable chance of default may have a high debt capacity if it can be easily sold for fundamental value when default occurs. If, on the other hand, cycical and growth assets are extremely illiquid in a recession, costs of financial distress are large, and financing these assets with debt is costly. Ajrline gates and routes, tankers and industrial equipment are poor candidates for debt finance precisely because industry buyers are themselves in trouble in a recession, and so these assets are highly illiquid. Illiquidity is an important reason for low debt capacity of cyclical and growth assets.

Cyclical industries might have an industry debt capacity even when debt capacity of individual firms is not wel!-defined. If other firms in the industry have little debt, a given Firm can afford to take on a lot of debt since it knows that in distress it can sell its assets without concessions to other firms who have significant unused debt capacity. On the 
other hand, if other firms have substantial debt, a given firm's assets become much less liquid and so it is much more costly for it to take on more debt itself. There might thus be an optimal debt level for the industry in which the benefits of debt are exactly offset by the extra illiquidity of the industry assets that additional debt entails. This notion of industry debt capaciry is particularly appropriate for industries with industry-specific assets, such as airlines. Managers of American Arlines and TWA -- the two remaining large airlines with a lot of cash and unused debt capaciry in 1990 -- have repeatedly said that they are waiting for the next crunct in the industry to pick up planes and routes from all the other firms that have taken on a lot of debt. With firm-specific or fungible assets, the notion of industry debt capacity is not well-defined.

The theory aiso predicts that smaller firms are ceteris paribus better candidates for debt finance than very large firms. The caveat is important because small firms might be uninteresting to very many buyers, since they are too specialized, in which case the thin market reason for illiquidity might be more importan than credit constraints of buyers. The way to test this prediction is to look at a market where firms of different sizes operate together, and to see if smaller ones have more debt. The theory also predicts that conglomerates are better candidates for debt finance than pure plays of the same size because they can be broken up into smaller pieces that are more liquid. Similarly, any business consisting of a loose affilation of different parts should have a high degree of debt capacity. For example, a company whose principal assets are 10 cable franchises in 
different cities has significant debt capacity.

A furher important implication of the theory is that some assets have debt capacity because they are traded by deep pocket investors though they would not have it if traded by industry buyers. For these assets, default is not very costly because they can be resold for a price close to value in best use. For example, cellular or cable TV properties have a high deb: capacity because they are traded by deep pockets investors such as telephone or media companies, who have access to cheap capital. Similarly, art favored by many rich investors, such as American Fop art or Impressionist art, car: be debt-financed even though it yields zero cash flow. The two main features of this art is first that many people like it, and second that these people have a high and persistent cash flow. The number of potential interested buyers is critical: American pop art has a liquid marker in the United States but no market in Europe, whereas German Expressionist paintings are liquid in Germany. These examples illustrate a key point: it is not just the low probability of Enancial distress but the low liquidity cost that creates debt capacity.

The empirical evidence of Titman and Wessels (1988) bears cn some of the predictions of our approach, although the authors are motivated by other theories. Titman and Wessels find that firms with unique assets, where uniqueness is measured by $R \hat{Q} D$

${ }^{5}$ Asset illiquidity also has implications for the structure of corporate debt and or corporate assets. For example, firms with illiquid assets are likely to choose longer term debt (see Diamond 1991). Firms would also alter the composition of their assets toward more liquid ones even at the cost of operational efficiency, to reduce the illiquidity costs discussed in this paper. For example, restaurants might buy furniture and equipment with greater resale value to get more money out in case they go bankrupt. 
intensity and selling expenses, have lower debt to equity ratios. They also find that firms with more intangible assets have lower debt equity ratios. Both of these results are consistent with asset non-fungibility deterring debt finance. Finally, Titman and Wessels find that smaller firms have higher debt equity ratios, also consistent with our theory. Most theories predict the opposite since smaller firms have higher transaction costs of external finance. Overall, the evidence lends some support for the importance of asset liquidity, but the tests clearly were not designed with this theory in mind.

7. Changes in liquidity over time.

Our discussion thus far has focused on cross-sectional variation in liquidity and in debt capacity. We next focus on changes in liquidity over time. Debt capacity is created not by today's liquidity, but by liquidity over some planning horizon during which it might become necessary to sell the asset. An asset has debt capacity during the period the market is expected to be liquid, so should the need arise to sell the asset, the discount to fundamental value will be small.

For most non-fungible assets, the two key determinants of liquidity are participation of industry and other informed buyers and the cash tlow of these buyers. Industry buyer participation tends to be determined by laws and other major institutional changes, and so is highly persistent. Corporate cash flows tend to be fairly persistent as well, largely because the conditions in an industry and in the economy typically change fairly slowly, 
Corporate cash reserves are probably even more persistent than cash flows, since stocks change less rapidly than flows. Because industry buyer participation and cash flow are persistent, it seems reasonable to assume that liquidity is fairly persistent as well. If a market is liquid today people probably expect liquidity to persist for a couple of years, during which it might become necessary to sell the asset. Today's liquidity is then generally associated with today's debt capacity.

Although liquidity is persistent, it does change over time. Changes in liquidity lead to changes in debt capacity. High markets are generally believed to be liquid and low markets to be illiquid. That is, fundamental values rise at the same time as prices come closer to fundamental values. Housing markets and markets for companies illustrate this principle. Below, we offer some reasons for the association between values and iquidity.

\section{Why high markets are liquid markets.}

The most important reason that liquidity changes over time, and that high liquidity goes together with high asset values, is that industry cash flows drive both value and liquidity and cash flows change over time. In particular, industry cash flows change dramatically over the business cycle. When industry buyers cash flows are high, their cost of capital is low since they can use internal funds to pay for the assets and can borrow on better terms. As a result, they can bid closer to their fundamental valuations for the assets. Also, fundamental values of assets rise with their own cast flows. In part, this is because 
current cash flows are part of the value, but also because there is a lot of persistence in cash flow, so buyers extrapolate current cash flow levels into the future.

We see, then, that the fundamental value of an asset rises with its own cash flow, and its liquidity rises with its potential buyers' cash flow. When cash flows of the asset and of its potential buyers rise at the same time, as they would in an industry or generai business upturn, both fundamental values and liquidity rise. In such markets, prices are high both because fundamental values are high, and because prices assets fetch are closer to these values. High markets are thus liquid markets. A lot of transactions often take place in such markets, since sellers are willing to part with their assets at prices close to already high fundamental values even without financial distress. In low markets, in contrast, sellers get prices below already low fundamentals because issets are illiquid. As a result, the only transactions that take place are those where sellers have to sell:

In high markets, a firm can borrow more in anticipation of being able to sell assets to other firms whose debt levels have not risen despite increases in their cash flow and value. As long as potential buyers have not leveraged up, a firm can count on unused debt capaciry of other firms to increase its own debt. For example, buyers of real estate in a boom rely on debt finance because they expect to be able to resell the buildings to others whose high cash flow can support greater debt. Lenders see this liquid resale market as well, and so lend on better terms. When so much new debt is taken on that no unused debt capacity remains, the only factor that sustains liquidity is self-fulfilling beliefs of buyers 
that they can sell. Such self-fulfiling equilibria can be very fragile, however, and cannot be sustained when liquidity falis for an exogenous reason, such as a scare in the junk bond market.

Other than cash flow, the critical determinant of both fundamental values and liquidity is the number of buyers. Changes in government regulation, or in buyer tastes, can bring new buyers into the market, particularly from the same industry. If these are high valuation buyers, this has the effect of raising fundamental values. The entry of new buyers also raises the liquidity of the assets as the opportunities for selling assets to these buyers are created. As liquidity rises, debt capacity tises as well because of the possibility of reselling to one of these new buyers.

\section{Self-fulfilling liquidity and debt capacity.}

In our discussion so far, we have focused on exogenous changes, such as those in cash flow or in the number of buyers, as the reasons for increased liqudity and debt capacity. But to some extent, these processes are self-reinforcing. When liquidity increases, by definition it becomes easier to sell assets at prices close to their values under best management. Someone who wants to buy a cifferent asset from the one he owns can sell the asset for a good price and buy another one. Such buyers would avoid an illiquid market because they would not be sure that they can sell their own assets on good terms. As such buyers enter the market, liquidity increases. In this way, liquidity is self-reinforcing, 
leading to multiple equilibria without exogenous shocks.

This analysis might be germane to housing markets, where people might try to buy houses only if they know that they can sell theirs on attractive terms. So when a housing market is liquid, many people are willing to be buyers and sellers, reinforcing this liquidity. In contrast, when a market is illiquid, people do not become buyers because they can't sell their old house at a good price, and so the market stays illiquid. In liquid markets, there are many transactions, high prices, and high debt capacity because the resale market is good. The reverse is true in illiquid markets. Similarly, corporations might trade divisions to find best matches in liquid markets because they know they can sell poor matches, and abstain from trading in illiquid markets thus keeping them illiquid.

There is an additional important feedback effect from debt capacity to liquidity. People borrow in liquid markets because resale is attractive. But resale is made more attractive by the opportunity for those future buyers to borrow at attractive terms. So good bortowing opportunities increase liquidity, which in turn improves borrowing opportunities. In our real estate example, buyers might choose debt finance precisely because they know that if they need to resell, other buyers would have access to debt finance. In this way, not only liquidity creates debr capacity; but debt capacity creates liquidity.

This feedback might be strong enough to generate multiple equilibria as well. In one equilibrium, assets are illiquid and are nor bought with debt because buyers recognize that other buyers in resale could not themselves borrow at attractive terms. In another 
equiliorium, assets are liquid and buyers use debt to finance them because they expect they can resell them to other buyers who will also have access to debt at atuactive tems. People can borrow solely because others they trade with can borrow. In principle, these two equilibria can coexist holding constant both the number of potential buyers and the cash flow. Liquidity and debt capacity can be self-fulfilling.

All these arguments point in the same direction. Some of the time, asset markets are high and liquid, with many transactions and substantial use of debt. This liquidity may be self-sustaining, but more likely it is helped by exogenous increases in cash flow or in the number of buyers. At other times, markets are low and illiquid, with few transactions, and much less reliance on debt to finance asset acquisitions.

8. Takeover waves and leverage increases: the experience of the 1980 s.

Perhaps the most interesting application of our theory is to the analysis of takeover waves. Asset acquisitions -- such as takeovers, selloffs and divestitures -- are highly procyclical (Golbe and white 1988). This fact is surprising unless one focuses on asset liquidity. If assets sell for their fundamental values, and if capital markets are perfect, there should be no cyclical pattern to acquisitions. If, in addition, some firms are sold off involuntarily when they are in financial distress, acquisitions should be countercyclical. In fact we observe the opposite.

Asset liquidity helps account for the evidence. In recessions, many asset buyers are 
credit constrained and cannot afford to pay the fundamental values for the assets. The sellers should then try to postpone the sale of assets until markets become more liquid. It is not so much that fundamental values are low when cash flows are low, but that prices are even lower than fundamental values when cash flows are low. By comparison, when cash flows are high, sellers can get prices close to fundamental values since buyers are not credit constrained. Sellers should therefore be willing to part with their assets more readily. As a result, the volume of transactions is highly procyclical.

High corporate cash flows have characterized every takeover wave in this century. In the 1980 s, however, an additional reason for increased liquidity was the increase in the number of buyers. Before 1986, the General Utilities doctrine combined with accelerated depreciation provided a tax reason for churning assets. In addition, there has been an influx of foreign acquirers, particularly in food, chemical, electronics and financial services industries. Even more importantly, much of the increase in the takeover activity in the 1980s was in horizontal mergers owing to relaxation of antitrust enforcement (Bhagat, Shleifer, and Vishny 1990). Bhagat et al demonstrate that, once selloffs are accounted for, over 70 percent of the assets of targets of hostile takeovers ended up in the hands of firms in the same industry as these assets.

The increase in the number and the cash flow of industry buyers raised liquidity and debt capacity, since firms could more easily take on debt expecting that they can sell assets and divisions at close to fundamental values if they cannot meet interest payments. In fact, 
many loans during this period were made with a clear understanding that cash flow was insufficient to pay interest from the beginning and assets must be sold to pay down debt. Asset sales were not an unlikely contingency, but a certainty for these loans. Asset liquidity was therefore essential for these loans to be made. In this way, the liquid market for firms and divisions made possible large increases in bank debt and junk bond financing in the 1980 s (Bemanke and Campbeil 1988, Warshawsky 1990).

Some of the increases in debt were part of the takeover financing, but many companies not involved in takeovers also increased debt. In fact the 1980 s saw an unprecedented increase in share repurchases by corporations, resulting in net retirements of equity by the corporate sector as a whole (Bagwell and Shoven 1988). Although one reason for these leverage increases may be takeover defense, another reason is the rise in the liquidity of assets, which greatly increased debt capacity. Quite aside from hostile takeovers, the liquid market for divisions enabled firms to take in more debt. Interestingly, Seth (1990) reports that debt increases have been particularly pronounced in cyclical industries, in which liquidity of assets rises sharply in economic expansions.

Many of the leveraged acquisitions of the 1980s, particularly the LBOs, would not have been possible were it not for the liquid market for divisions. This new active market for large firms and their divisions - spawned in part by the relaxation of antitrust enforcement and in part by financial innovation -- created the possibilities for debt finance conditional on rapid resale of assets, a practice essential for LBOs. Bhagat et al (1990) 
document that on average 30 percent of assets were sold following a hostile takeover in the 1980s; this average is 40 percent for LBOs. Bustup takeovers is the extreme example of borrowing in anticipation of selling assets. Debt Enance in anticipation of a resale of pars in a liquid market made the takeover wave of the 1980 s so large and so concentrated among the large companies.

When companies were not optimally managed, their assets could be sold at prices above their values as part of these companies. In this case, the costs of financial distress were negative, since assets could be liquidated for more than their status quo values. The increased liquidity of the market for assets raised division prices in divestitures enough that busting up mismanaged conglomerates became profitable when it was not profitable before. In this way, increased liquidity might have made efficiency improvements possible.

The view that the liquidity in the market for corporate assets increased debt capacity contrasts with the conventional view. That view credits junk bonds and other financial innovations with increased takeovers since junk bonds permitted the raiders to attack large companies. Our view is that the liquidity of the market for companies made junk bonds possible and not the other way around. First, takeover waves take place in many economic booms, and many takeovers were financed with debt before junk bonds were invented. Second, junk bonds did not really become important until 1985 , several years after the takeover wave of the 1980 s became big (Kaplan and Stein 1990). This fact suggests that taking on junk debt became attractive only after the market for assets became liquid 
enough. Liquidity seems to have created debt capacity and not the other way around in the 1980 s takeovers, although of course there were important feedback effects as well.

9. Conclusion.

The starting point of this paper is that asset liquidity is an extremely important determinant of the costs of tinancial distress. Among several reasons for asset illiguidity we have identified are non-fungibility as well as regulation and credit constrants that reduce participation and ability to pay of the industry buyers. Because assets of furms in financial difficuity are particularly illiquid -- as their buyers are likely to be in financial difficulty themselves -- selling off these assets might be very costly. The high concessions sellers must make if they sell off assets in illiquid markets reduce ex ante debt capacity since they raise the costs of financial distress. We have argued that this approach can be used to understand both cross-sectional variation in leverage, and the changes in leverage over time.

We have not addressed the sudden end of the takeover wave of the 1980 , and in particular of junk bond issues and LBOs. Many of the leveraged buyouts and takeovers of the late 1980 s were carried out on the expectation that the liquidity of the market for divisions would persist. The persistent liquidity assured attractive asset sales and therefore made debt financing possible. In 1989 , asset liquidity suddenly declined. Some of the causes were exogenous, such as the forecasted recession, the collapse of Drexel and the junk bond market, and the troubles of some visible LBOs such as Campeau and Southland. 
In addition, investors, scared by the few bad episodes, no longer expected markets for divisions to be liquid, which of course meant that they no longer were.

The troubles of the junk bond market meant that new LBOs could not be easily financed and old ones refinanced. But even seasoned LBOs that did not rely on further junk bond financing ran into trouble because their assets became illiquid. Many of these LBOs counted on asset sales to pay down debt. Asset illiquidity reduced proceeds from asset sales below previously expected levels, making debt repayment more difficult. In addition, asset illiquidity further weakened the junk bond market, since investors in junk bonds relied on asset sales for principal repayments. The troubles of the junk bond market and declines in asset liquidity reinforced each other, since asset liquidity crucially depends on financing, and financing relies on liquidity. Until the liquidity of corporate assets recovers, the troubles of many LBOs are likely to continue. 
Bibliography.

Bagwell, Laurie S. and John B. Shoven. "Cash Distributions to Shareholders." Joumal of Economic Perspectives 3 (Summer 1989), 129-140.

Bernanke, Ben and Johr Y. Campbell. "Is there a Corporate Debt Crisis?" Brokings Papers on Economic Activity (1988:1), 83-125.

Bemanke, Ben, John Y. Campbell and T. Whited. "U.S. Corporate Leverage: Developments in 1987 and 1988." Brookings Papers on Economic Activity (1990:1), 83-139.

Bemanke, Ben and Mark Gertler. "Agency Costs, Collateral, and Business Fuctuations." American Economic Review 79 (March, 1989), 14-31.

Bhagat, Sanjai, Andrei Shleifer, and Robert W. Vishny. "Hostile Takeovers in the 1980s: the Retum to Corporate Specialization." Brookings Papers on Econonic Activity: Microeconomics (1990), $1-84$.

Diamond, Douglas W. "Debt Maturity Structure and Liquidity Risk." Quarterly Jommal of Economics CV (1991), forthcoming.

Froot, Ken and Jeremy C. Stein. "Exchange Rates and Foreign Direct investment: an Imperfect Capital Markets Approach." Quarterly Journal of Economics CV (1991), forthcoming.

Gertler, Mark and R. Glenn Hubbard. "Financial Factors in Business Fluctuations." in Financia! Market Volatility, Federal Reserve Bank of Kansas City (1988).

Gertner, Robert and David S. Scharfstein. "A. Theory of Workouts and the Effects of Reorganization Law." University of Chicago Manuscript (1990).

Golbe, Devra Lo and Lawrence J. White. "A Time Series Anlalysis of Mergers and Acquisitions in the U.S. Economy." In Alan J. Auerbach, editor, Corporate Takeovers: Causes and Consequences. Chicago: University of Chicago Press (1988).

Greenwald, Bruce, Joseph E. Stiglitz and Andrew Weiss. "Information imperfections in the Capital Market and Economic Fluctuations." American Economic Review 74 (May 1984), 194-199. 
Grossman, Sanford J. and Merton H. Miller. "Liquidity and Market Structure" Journal of Finance 43 (July 1988), 617-633.

Harris, Milton and Artur Raviv. "Capital Structure and the Informational Role of Debt." Journal of Finance 45 (June 1990), 321.349.

Holland, Max. When the Machine Stopped. Harvard Business School Press (1990).

Kaplan, Steven N. "Campeau's Acquisition of Federated: Value Destroyed or Value Added?" Joumal of Financial Economics 25 (December 1989), 191-212.

Kaplan, Steven N. and Jeremy C. Stein. "How Risky is Debt in Highly Leveraged Transactions: Evidence from Public Recapitalizations." Journal of Financial Economics (1990), forthcoming.

Myers, Stewart. 'The Capital Structure Puzzle." Joumal of Finance 39 (July 1984), 575-92.

Seth, Rama. "Leverage and Cyclicality." Working Paper, Federal Reserve Bank of New York (September 1990).

Titman, Sheridan and Roberto Wessels. "The Determinants of Capital Structure Choice." Journal of Finance 43 (March 1988), 1-20.

Warshawsky, Mark "Is there a Corporate Debt Crisis? Another Look" Finance and Economics Discussion Series Paper No. 110, Federal Reserve Board (February, 1990).

Williamson, Oliver E. "Corporate Finance and Corporate Governance." Journal of Finance 43 (July 1988), 567-592. 